\title{
Forest Resources Depletion: An Ecological Model for Biodiversity Preservation and Conservation in Cote D'Ivoire
}

\author{
Christian Jonathan Anoma Kouassi', Dilawar Khan1, Lutumba Suika Achille1, \\ James Kehinde Omifolaji ${ }^{2,3}$, Zhang Kebin ${ }^{1 *}$
}

${ }^{1}$ School of Soil and Water Conservation, Beijing Forestry University, Beijing, China

${ }^{2}$ School of Ecology and Nature Conservation, Beijing Forestry University, Beijing, China

${ }^{3}$ Department of Forestry and Wildlife Management, Federal University Dutse, Nigeria

Email: anoma@bjfu.edu.cn, Dilawarafridi333@bjfu.edu.cn, achille@bjfu.edu.cn, *ctccd@bjfu.edu.cn

How to cite this paper: Kouassi, C.J.A., Khan, D., Achille, L.S., Omifolaji, J.K. and Kebin, Z. (2021) Forest Resources Depletion: An Ecological Model for Biodiversity Preservation and Conservation in Cote D'Ivoire. Open Journal of Ecology, 11, 870-890.

https://doi.org/10.4236/oje.2021.1112052

Received: November 18, 2021

Accepted: December 27, 2021

Published: December 30, 2021

Copyright $\odot 2021$ by author(s) and Scientific Research Publishing Inc. This work is licensed under the Creative Commons Attribution International License (CC BY 4.0).

http://creativecommons.org/licenses/by/4.0/

\begin{abstract}
The biodiversity-rich primary forest of Cote d'Ivoire has been substantially converted into a mosaic of secondary forests, cash and lumber plantations, food crops, and timber plantations, food crops, and wasteland. Deforestation started even before independence but has increased dramatically in the last three decades, resulting in the loss of most of the country's biodiversity. It is essential to have information about the condition of the country's natural resources following many human pressures. This research aimed to examine the Cote d'Ivoire Phytogeographical zones to understand the state of the wood's ad wildlife in 2020 about the anthropic pressure on the whole Ivorian land. The Land-Use Planner approach has been used as a tool for creating a model for preserving biodiversity. There are 15 endangered tree species recognized, five each phytogeographical zone. Buffaloes are seen and distributed in the West and north of Cote d'Ivoire, duikers are observed in nearly all phytogeographical zones, elephants are observed in the West and North. At the same time, harnessed guibs are observed and dispersed across the nation, according to the findings. In terms of endangered tree species, the most frequent endangered trees species in the country's south are Strombosia pustulata (6.2\%), Diospyros mannii (5.1\%), Protomegabaria stapfiana (3.7\%), Musanga cecropiodes (3.6\%), and Xylopia quintasii (3.2\%). In the Middle Tectona grandis accounts for (11.8\%), Nesogordonia papaverifera accounts for (4.2\%), Cedrela odorata accounts for (3.7\%), and Gmelia Arborea accounts for $(2.8 \%)$. In the North, Isoberlinia doka accounts for (10.3\%), Upaca togoenisis accounts for $8.9 \%$, Anogeisssus leicarpa accounts for (5.1\%), Pterocarpus erinaceus accounts for (4.6\%), and Pericopsis laxiflora accounts for (3.9\%). In reforested woods, the volume of merchantable wood timber of the
\end{abstract}


P1, P2, and P3 categories per hectare is more significant than in wild forests. We find that biodiversity is severely endangered. Endemic species have decreased due to human activities like agriculture and logging, which are the root causes of deforestation and animal and plant biodiversity loss.

\section{Keywords}

Endemic Species, Deforestation, Cote d'Ivoire, Land-Use Planner, Phytography

\section{Introduction}

Forests, because of their ecological resources, play a vital role in human existence. Several international conferences of various organizations are focused on the preservation on the preservation and protection of its biodiversity [1]-[6]. Forests provide indirect benefits by helping to sustain and control biophysical components of the ecosystem, such as climate and water [7] [8] [9] [10]. Tropical forest ecosystems are globally recognized for their benefits and services to humans [11]-[17]. The resilience of these ecosystems and the sustainability of the products and services they offer are significant concerns in the context of global change and the climate component [18] [19]. Forests, in particular, have played an essential role in the biogeochemical control of the carbon and water cycles, the supply of wood and non-wood forest products, and the provision of cultural and customary services through Africa [20]. The resilience of these ecosystems and the sustainability of the products and services they offer are significant concerns in the context of global change and the climate component [19].

Forest plays a vital part in human existence due to its ecological resources. Forests assist in sustaining and controlling the ecosystem's biophysical features, such as climate and water, as co-benefits. Forests in Cote d'Ivoire, especially in rural regions, offer numerous essential services to preserve rural livelihoods and lifestyles. According to the country's official website, the most recent forest inventory in Cote d'Ivoire was conducted in 1978 in the country's southern area. Since then, the government has worked hard to establish a sustainable balance between forest and agricultural production and the maintenance or restoration of ecosystem services on which both sectors rely while also maintaining or improving the environment. In addition, it has committed to reducing greenhouse gas emissions and maintaining a forest cover covering at least $20 \%$ of the country's land area by 2020, both of which are ambitious goals. Even though it must satisfy the rising demand for timber and service wood (for national and regional markets), it must also meet an increasing need for firewood and charcoal, which is particularly essential in a dry region with limited wood output. Forest cover must be restored due to this combined environmental and economic problem, with the first step being the restoration of classified forests. Because of this, cocoa plantations and other crops would have to be destroyed, presenting a signif- 
icant social and political risk to the local communities [21]. In particular, the adoption of agroforestry methods and the development of cash and food crop production will help to reduce these emissions, among other things. The adoption of agricultural forestry and environmental policies by the Ivorian government will help to address these problems. It is one of the foundations for implementing the country's plan to use the research results, which shows the state of forests and wildlife in 2020 about human pressure on the whole Ivorian territory, to implement its plan. Like Latin America and the Caribbean, the Pacific, and Africa, Cote d'Ivoire has many tropical forest resources available to the global community [12] [22] [23] [24] [25] [26]. Despite the political effort to preserve and restore these forests, we are worried about the continuing depletion of forest resources in general and the depletion of state-protected forests in particular [27] [28].

According to the [28] [29], the yearly deforestation rate of tropical forests remains exceptionally high in Africa: $0.62 \%(4,040,000 \mathrm{ha})$ and $0.51 \%(4,483,000$ ha) in Latin America and the Caribbean [29], whereas Europe and Asia have witnessed an increase in forest cover. This seems to be a contradiction. Forest provides numerous benefits and services to humanity [30] [31] [32] [33] [34]. They are, in fact, the foundation for biodiversity conservation and condition the existence of animal, plant species and solve the climate crisis [35]-[43]. Despite their significance, human pressure on forest resources is now a danger to the long-term viability of the products and services they offer [44] [45] [46] [47]. The establishment of protected areas in Cote d'Ivoire, like in other French-speaking African nations such as the Central Africa Republic, Cameroon, Congo Brazzaville, and Gabon, was done by the French government before the country's independence in 1960 [48]. The colonial administration's goals in creating all of the forest reserves of the "forest domain" were to avoid deforestation in the nation, establish a sizeable classified area, preserve and enhance this domain, and form vegetal climatic barriers [49]. These state-protected areas are currently utilized as biodiversity conservation sites and storage facilities for goods and services for the benefit of the local population [32] [48] [50].

However, due to rapid population growth, widespread agricultural, and high demand for wood, there is a rising demand for agricultural land and increased cultivated land prices [51] [52] [53] [54]. Hundreds of hectares of Ivorian forest are destroyed each year due to human activities in the nation [55] [56] [57]. The rate of deforestation is believed to be over $90 \%$, putting Cote d'Ivoire at the top of the list of tropical African nationals experiencing a decrease in forest areas [58] [59] [60] [61]. Deforestation is usually caused by farmers removing land for farming. To a lesser degree, it is also related to the growth of agro-industrial crops and logging [62].

According to the United Nations Development Program, this places Cote d'Ivoire among the countries with the highest deforestation rates [63] [64]. According to the World Resources Institute, the dense rainforest fell from 16 million hectares at the end of the eighteenth century [65] to 9 million hectares in 1965 and then 
to 2.7 million hectares in 2014 [66]. According to the report, agricultural fronts in Cote d'Ivoire do not spare any plant formation, whether protected (in a protected area) or not, showing the severity of the country's pressure on forest resources. Over the last decade, the United Nation Program for ecological restauration has encouraged countries to develop strategic plans for ecosystem protection and conservation to ensure ecosystem services to local populations while mitigating the effects of global warming

(https://www.decadeonrestoration.org/). As a result, the designated forest of Cote d'Ivoire is based on data from the socioeconomic survey and data on animal and plant biodiversity to precisely know the state of forest resources in 2020 and build a model of preservation and conservation biodiversity.

\section{Materials and Methods}

\subsection{Study Area}

Cote d'Ivoire is a West African nation and African Union Member. It is bounded to the North by Mali and Burkina Faso, to the West by Liberia and Guinea, to the East by Ghana, and to the South by the Atlantic Ocean. In 2004 , the population was protected to $22,671,331$ people. Cote d'Ivoire's territory is located between $5^{\circ}$ and $10^{\circ}$ north latitude, about 400 kilometers from the equator on its southern boundaries and approximately 14,00 kilometers from the Tropic of Cancer on its northern borders (Figure 1). The climate is usually hot
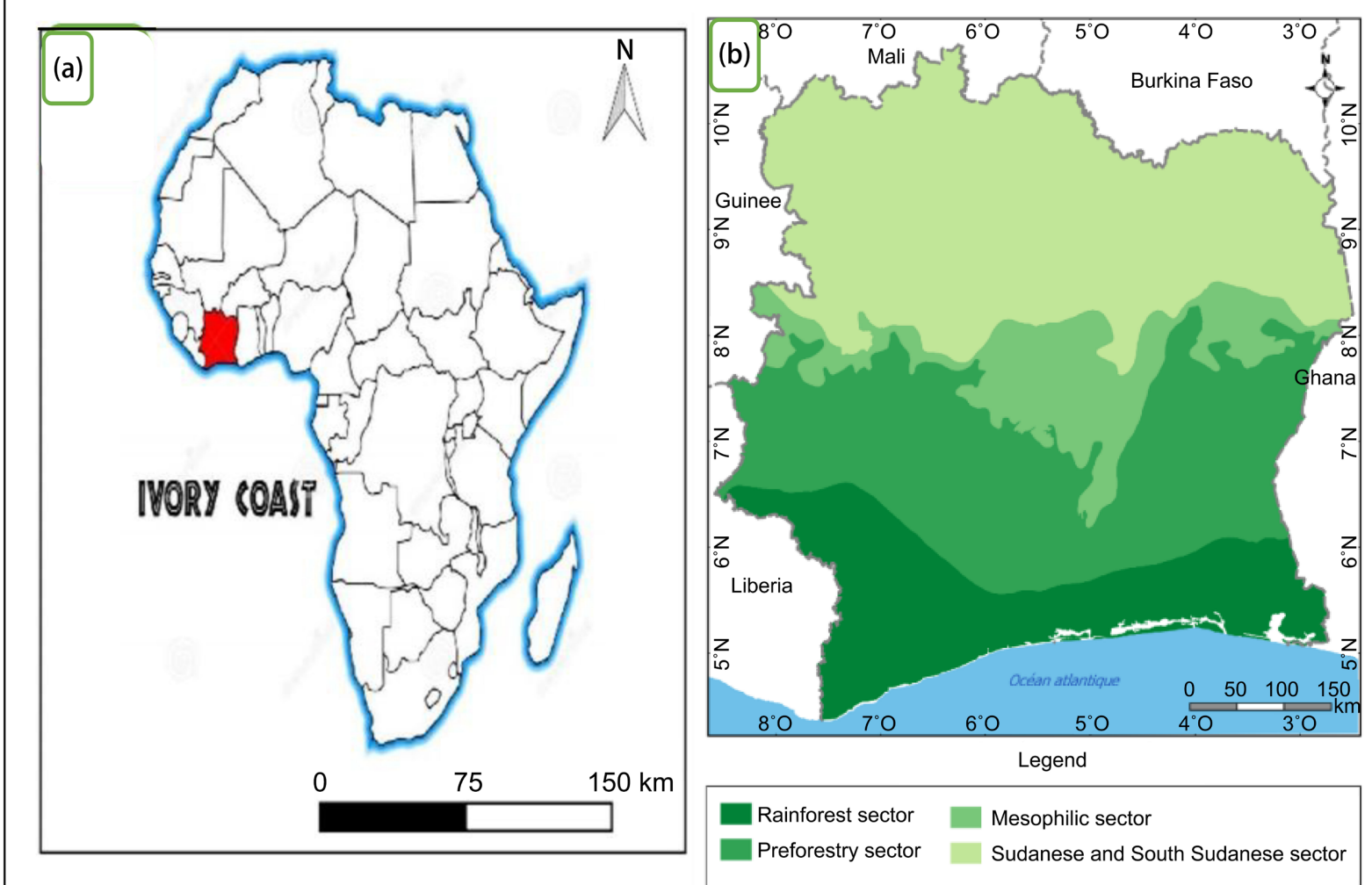

Figure 1. Study area: (a) African map; (b) Cote d'Ivoire map with different phytogeographic area. 
and humid and therefore falls between equatorial and tropical. It is equatorial near the coastlines and semi-arid in the far north. On average, temperatures hover around $28^{\circ} \mathrm{C}$. There are two major climatic zones: equatorial climate and tropical savannah climate, which is mostly dry.

The brief dry season lasts from August through September. May to July is the wet season, while October to November is the short season. Tropical humid savannah climate is found in the southern forest zone and the southern savannah area. In the center of the nation, temperatures vary from $14^{\circ} \mathrm{C}$ to $33^{\circ} \mathrm{C}$, with humidity ranging from $60 \%$ to $70 \%$ and an annual rainfall of $1200 \mathrm{~mm}^{3}$. Cote' Ivoire is a low-lying nation. The vast majority of the terrain is made up of plateaus and plains. The western portion of the country, which is hilly, has a few elevations over a thousand meters (Mount Nimba reaches $1752 \mathrm{~m}$ ). Aside from this area, elevations typically range between 100 and $350 \mathrm{~m}$. the main characteristic of these plateaus is ferruginous armor stone, which is visible on the surface in the form of rust-colored slabs but is occasionally obscured by sand, gravel, or more delicate materials.

\subsection{Management, Conservation, and Preservation Model}

The Land-use Planner is a dynamic economic tool that may inform land-use planning procedures [67] [68] [69]. It assists stakeholders in developing participative and straightforward land-use scenarios, comparing social, economic, and environmental effects, and estimating the costs and benefits of policy choices [70] [71]. Informs land-use decisions at the jurisdictional level and may assist a particular area or supply chain in migrating to deforestation-free commodities production [72] [73]. It is a critical instrument for tackling the causes of deforestation and degradation, such as shifting agriculture and land insecurity, logging, and so on [74] [75].

To aid in the choice of development alternatives, a modeling tool called "Land-Use Planner" has been created for land use planning and the construction of an ecological network (Figure 2). This application allows for the simulation of various planning alternatives and evaluating the related cost and benefits to choosing the best solutions. The other options are based on the recognized direct and indirect causes of deforestation and forest degradation in Cote d'Ivoire. Agriculture, the primary economic driver (cocoa (world's largest producer), cashew nuts (world's seventh-largest producer), coffee, palm oil, Mango, Pineapple, dessert banana, cotton, cola, and so on), has been the primary driver of deforestation for the past 25 years. Industrial logging and custom sawing are characterized by a shortage of resources, resulting in unapproved diameter wood; illegal artisanal logging, which is on the rise. Wood energy, charcoal, which is, therefore, the primary source of household cooking energy (firewood dominates in rural regions; charcoal dominates in urban areas), is a significant economic sector practiced mainly in the informal sector, and animal poaching primary source of protein in rural areas. 


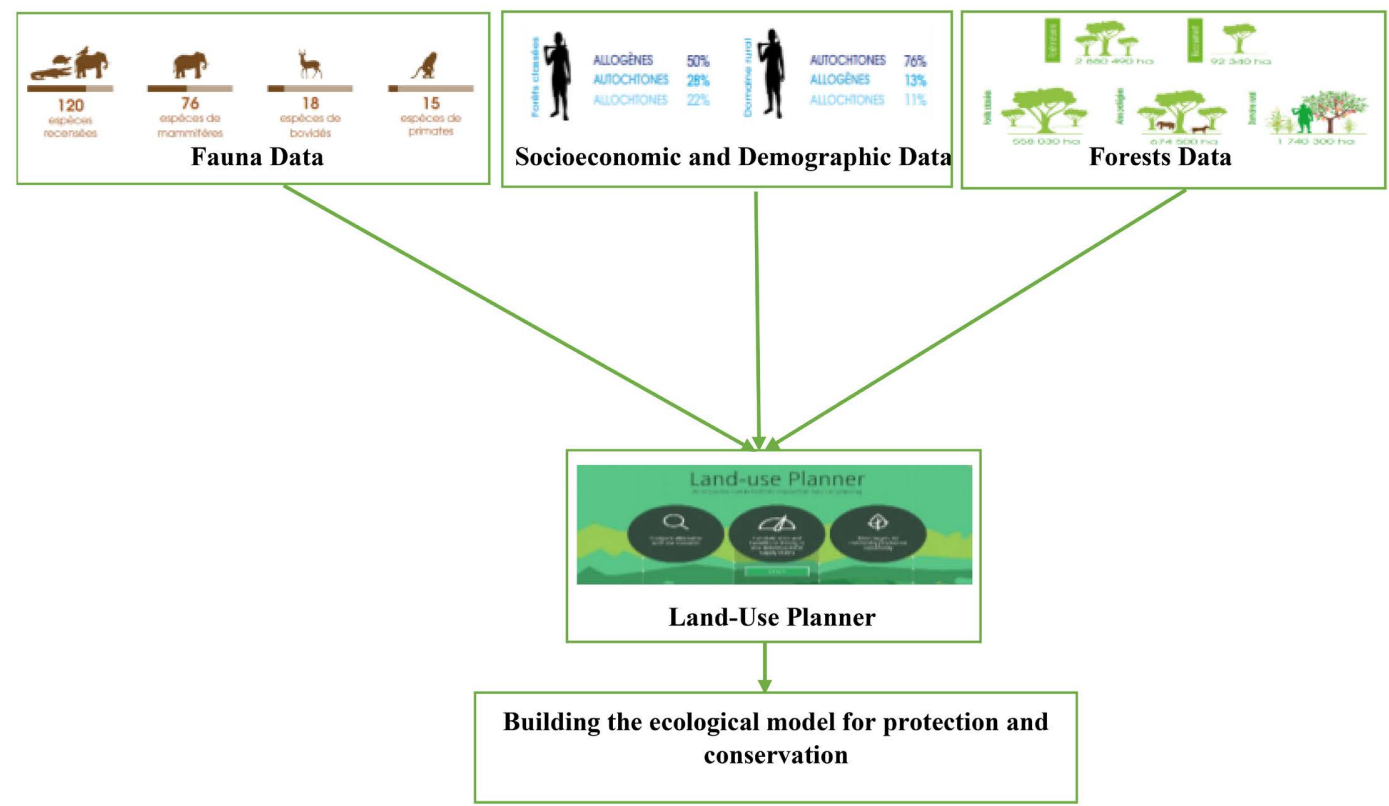

Figure 2. Methodology Study workflow.

\subsubsection{Fauna Data}

In 2019, the animal and forests resources data were collected throughout Cote d'Ivoire, particularly in parks and reserves (https://eauxetforets.gouv.ci/). For animals, 76 species of mammals, 18 species of bovids, and 15 species of primates have been collected.

\subsubsection{Socioeconomic Data}

Regarding socioeconomic data, 1767 people were interviewed, 65\% living inside forests and $35 \%$ living in rural regions (Table 1). According to the, $45 \%$ were Ivorian (indigenous people), $18 \%$ were allochthonous, and 33\% were other allogenic.

Table 2 shows the crops produced in designated forests and rural areas. We can see that cocoa is the main crop at $71 \%$, followed by cashew at $16 \%$, which varies from a rural region. Furthermore, fruit tree cultivation happened in many classified forests, with $68 \%$ occurring in forest regions, $50 \%$ occurring in rural areas, and $61 \%$ occurring overall.

\subsubsection{Forests Data}

During the sample selection, 1366 sample units were, and measurements were collected on 306,377 trees with diameters of $10 \mathrm{~cm}, 7412$ regeneration stems, and 29,203 dead trees and stumps.

\subsection{Abundant Endemic Tree Species}

Equation (1) was used to calculate species abundance in the Southern, Central, and Northern agroecology in 2020.

Species density By area $(\%)=\frac{\text { Number of stems per ha of Specie(i) }}{\text { Total number of stems }}$ 
Table 1. Distribution of population categories in Cote d'Ivoire (https://eauxetforets.gouv.ci/).

\begin{tabular}{cccc}
\hline Inside the classified forests & Percentage & Rural area & Percentage \\
\hline Allogenic & $50 \%$ & Autochthons & $76 \%$ \\
Autochthons & $28 \%$ & Allogenic & $13 \%$ \\
Allochthones & $22 \%$ & Allochthones & $11 \%$ \\
\hline
\end{tabular}

Table 2. Percentage of respondents reporting growing one of the five perennial crops (https://eauxetforets.gouv.ci/).

\begin{tabular}{cccc}
\hline Inside the classified forests & Percentage (\%) & Rural Area & Percentage (\%) \\
\hline Cocoa & 71 & Cashew & 59 \\
Cashew & 16 & Cocoa & 25 \\
Hevea & 8 & Hevea & 11 \\
Coffee & 4 & Oil Palm & 4 \\
Oil palm & 1 & Coffee & 1 \\
\hline
\end{tabular}

\section{Results}

The following species are prevalent in the forests of Cote d'Ivoire: Harnessed Guibs drum in hand. Three species account for more than $40 \%$ of the observations in the ecologies: the harnessed Gui, the hare, and the Aulocode. African atherure, Giant porcupine, Warthog, Bushpig, and large-billed touraco are among the region's most common and well-documented animals. Maxwell's and red-sided duikers, as well as the yellow-backed duiker, are among them. Buffaloes, chimpanzees, and Elephants are among the rarest species that can only be found in national parks and other protected areas. There are only Pygmy Hippopotamuses in the world, and they may be found at Tai National Park. There are 22 wholly protected species and 34 species on the IUCN red list, including five critically endangered species (e.g., Armoured crocodile, Panther, Cercopithecus Diana, and Magistraste, Chimpanzees) and nine endangered species. Figure 3 depicts maps of animal species sightings throughout the region. It focuses on the significant ecological settings where animal species may be found.

\subsection{Ecological Area}

According to the information gathered from the research, most thick forests in Cote d'Ivoire are concentrated in the rainforest and mountain sectors, covering 517,000 hectares. Indeed, protected areas account for $88 \%$ of these forests, with classed forests accounting for a little more than $10 \%$ of the total, particularly Cavally in the West, Mabi and Yaya Forest in the East. They serve as a storage facility for biomass as well as plant and animal biodiversity. Table 3 depicts the total distribution of forest in Cote d'Ivoire. 


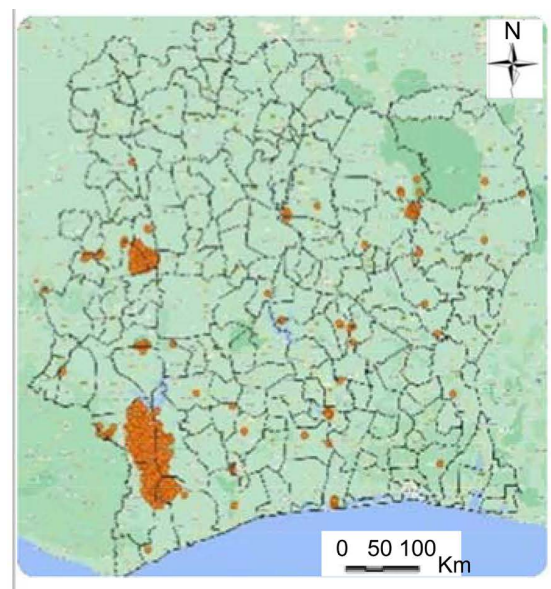

(a) Buffaloes

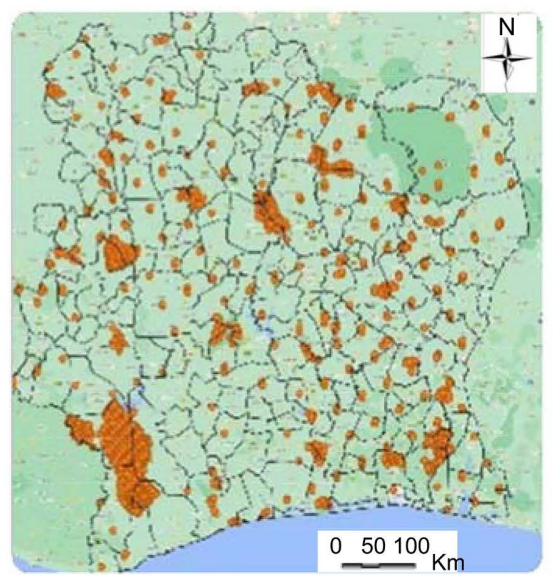

(b) Duiker

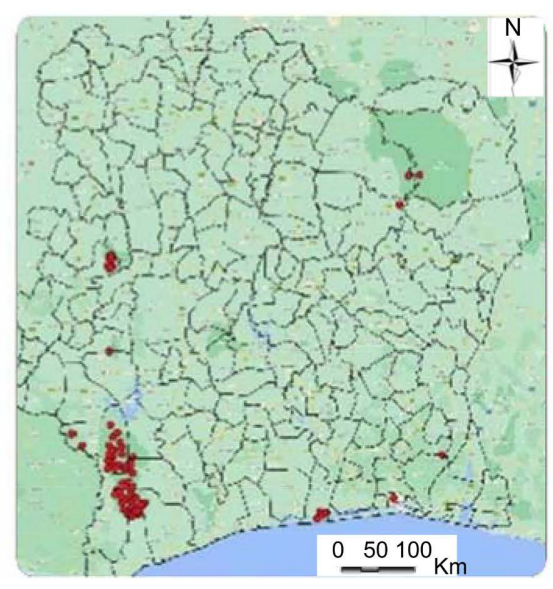

(c) Chimpanzees

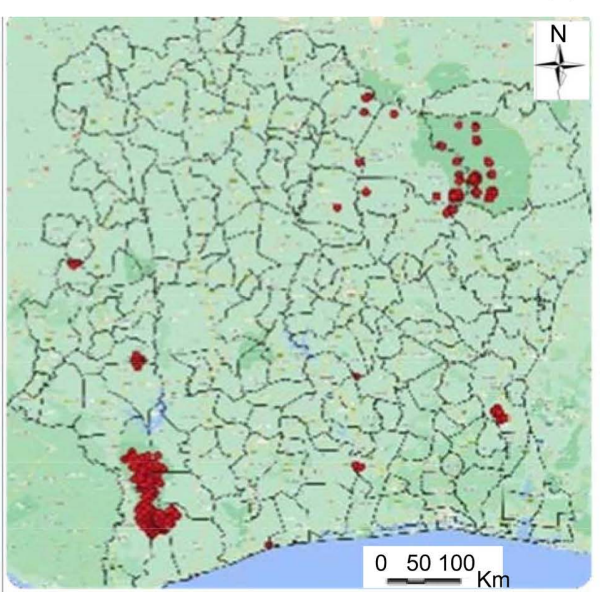

(d)Elephant

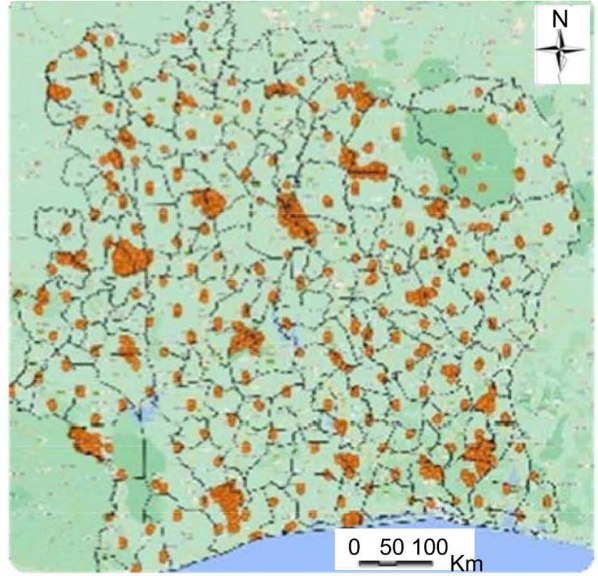

(e) Guibs Harnesses

Figure 3. Spatial distribution of animal species (a) Buffaloes; (b) Duiker; (c) Chimpanzees; (d) Elephants; (e) Guibs Harnesses (https://eauxetforets.gouv.ci/).

Table 3. Total distribution of forest in Cote d'Ivoire in hectare.

\begin{tabular}{ccccccc}
\hline Ecosystem & $\begin{array}{c}\text { Natural } \\
\text { forests }\end{array}$ & Reforestation & $\begin{array}{c}\text { Classified } \\
\text { forests }\end{array}$ & $\begin{array}{c}\text { Protected } \\
\text { areas }\end{array}$ & $\begin{array}{c}\text { Rural } \\
\text { area }\end{array}$ & $\begin{array}{c}\text { Total } \\
\text { (ha) }\end{array}$ \\
\hline $\begin{array}{c}\text { Hectares } \\
\text { (ha) }\end{array}$ & $2,880,490$ & 92,340 & 558,030 & 674,500 & $1,740,300$ & $5,393,210$ \\
\hline
\end{tabular}

The secondary forest comprises a wide range of different facies that vary from moderately to highly degraded by logging, partly cleared, regenerated after removing, etc. The total area of secondary forest forests is 523,000 hectares. They are often severely degraded in classified forests, but they include an abundance of regeneration of exploitable species, making them appealing for logging.

Almost $80 \%$ of open forests in the sub-Sudanese and Sudanese sectors are rural; they represent 1,194,000 ha. They are underutilized for wood and are under danger from agricultural clearance of specific crops such as cashew nuts and cotton.

Along the river, one-thirds are in the sub-Sudanese and Sudanese sectors. 
More than $80 \%$ of them are situated in rural areas and spanning 302,200 hectares. They serve as plant biodiversity reservoirs and reservoirs and natural wildlife corridors.

They result from the degradation of open forests; the wooded savannah is enclosed between and crossed by forest galleries. It represents 344,300 ha. The densest (13\%) are considered to be a forest. More than $96 \%$ is in the sub-Sudanese and Sudanese area. Almost $57 \%$ are in rural areas. Like the open forest, they are increasingly threatened by agricultural clearing $(\mathrm{Ca}$ shew, Cotton).

\subsection{Exploitable Timber Volume of Marketable Species Marketable Timber (Quality A: $\theta \geq 50 \mathrm{~cm}$; Quality B: $\theta \geq 40 \mathrm{~cm}$ )}

The amount of commercial wood species is shown in Table 4 and Table 5. Table 4 indicates that species from the reforested mountain and mesophilic forests are more marketable than those from the sector (Ombrophilic + Mountain + Mesophilic) in the natural forest 19 trees/hectare is much lower than in reforested regions 47 trees/hectare (Table 5). The same is true for categories P1 and P2 (14 trees/hectare) for the natural forest versus (46 trees/hectare), as well as for the barrel volume of category P1 and P2 (95 trees/hectare) versus (110 trees/hectare); except for the barrel volume (16 trees/hectare) for the natural forest of category P1, $\mathrm{P} 2$, and $\mathrm{P} 3$, where the total number of barrel volume of the natural forest is more significant than that reforested forest. We can see from the balance sheet that has been a considerable loss of trees.

Table 4. Volume of harvestable timber of marketable species $\theta \geq 50 \mathrm{~cm}$ in natural forest (https://eauxetforets.gouv.ci/).

\begin{tabular}{ccccc}
\hline & \multicolumn{2}{c}{$\begin{array}{r}\text { Category P1, P2 et } \\
\text { P3- } \boldsymbol{\theta} \geq \mathbf{5 0} \mathbf{~ c m}\end{array}$} & \multicolumn{2}{c}{$\begin{array}{c}\text { Category P1 et } \\
\text { P2 }-\boldsymbol{\theta} \geq \mathbf{5 0} \text { cm }\end{array}$} \\
\hline Natural forest & $\begin{array}{c}\text { Number } \\
\text { trees/ha }\end{array}$ & $\begin{array}{c}\text { Barrel volume } \\
\left(\mathrm{m}^{3} / \mathrm{ha}\right)\end{array}$ & $\begin{array}{c}\text { Number } \\
\text { trees } / \mathrm{ha}\end{array}$ & $\begin{array}{c}\text { Barrel volume } \\
\left(\mathrm{m}^{3} / \mathrm{ha}\right)\end{array}$ \\
\hline Ombrophilic Mountain & 9 & 57 & 5 & 39 \\
Mesophilic & 10 & 59 & 9 & 56 \\
\hline
\end{tabular}

Table 5. Volume of harvestable timber of marketable species $\theta \geq 40 \mathrm{~cm}$ in reforestation forest (https://eauxetforets.gouv.ci/).

\begin{tabular}{ccccc}
\hline & \multicolumn{2}{c}{$\begin{array}{c}\text { Category P1, P2 } \\
\text { et P3- } \boldsymbol{\theta} \geq \mathbf{4 0} \mathrm{cm}\end{array}$} & $\begin{array}{r}\text { Category P1, P2 } \\
\text { et P3- } \boldsymbol{\theta} \geq \mathbf{4 0} \mathrm{cm}\end{array}$ \\
\hline Reforestation & $\begin{array}{c}\text { Number } \\
\text { trees } / \text { ha }\end{array}$ & $\begin{array}{c}\text { Barrel volume } \\
\left(\mathrm{m}^{3} / \mathrm{ha}\right)\end{array}$ & $\begin{array}{c}\text { Number } \\
\text { trees } / \text { ha }\end{array}$ & $\begin{array}{c}\text { Barrel volume } \\
\left(\mathrm{m}^{3} / \mathrm{ha}\right)\end{array}$ \\
\hline Ombrophilic Mountain & 27 & 65 & 26 & 62 \\
Mesophilic & 20 & 48 & 20 & 48 \\
\hline
\end{tabular}


The density estimate of endemic tree species abundance diminishes in Cote d'Ivoire's northern, middle, and southern phytogeographic zones. Figures 4-6 demonstrate that the most prevalent species in each agroecology do not surpass $12 \%$. Gmelia Arborea (2.8\%, Figure 4) is the least dominant species in the country's central region, followed by Pericopsis laxiflora (3.9\%, Figure 5) in the south, and lastly, Xylopis Quintas (3.2 \% Figure 6) in the northern agroecology.

Figure 7 depicts a medium and long-term plan for integrated management to address the causes of deforestation and forest degradation through integrated landscape management of forest systems and the avoidance of ecological disasters.

The data show the time series of average annual maximum temperatures and yearly rainfall reported at meteorological stations in the northern (Ferkessédougou), central (Bouake), western (Man), and southern (Abidjan) regions from 1980 to 2020 (http://app.climateengine.com/).

According to the variation in precipitation in the southern, central, and western parts of the country, where the bulk of the forests are located, exceeds 1500 kilometers each year. An average monthly rainfall variance of more than $1500 \mathrm{~mm}$ between 2015 and 2020 indicates that these areas regularly get an

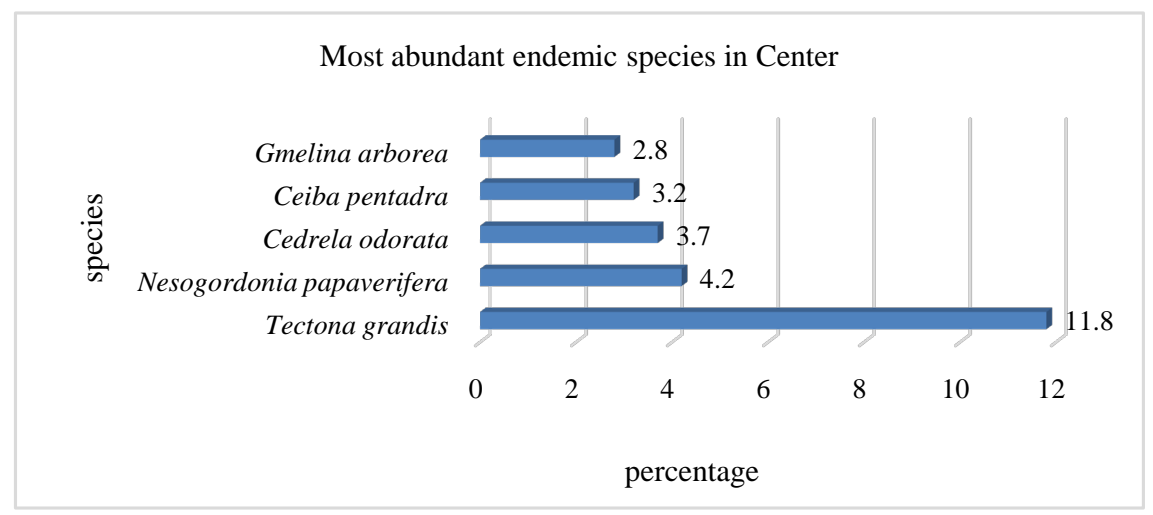

Figure 4. The abundance of endemic species in the agroecology in Center of Cote d'Ivoire.

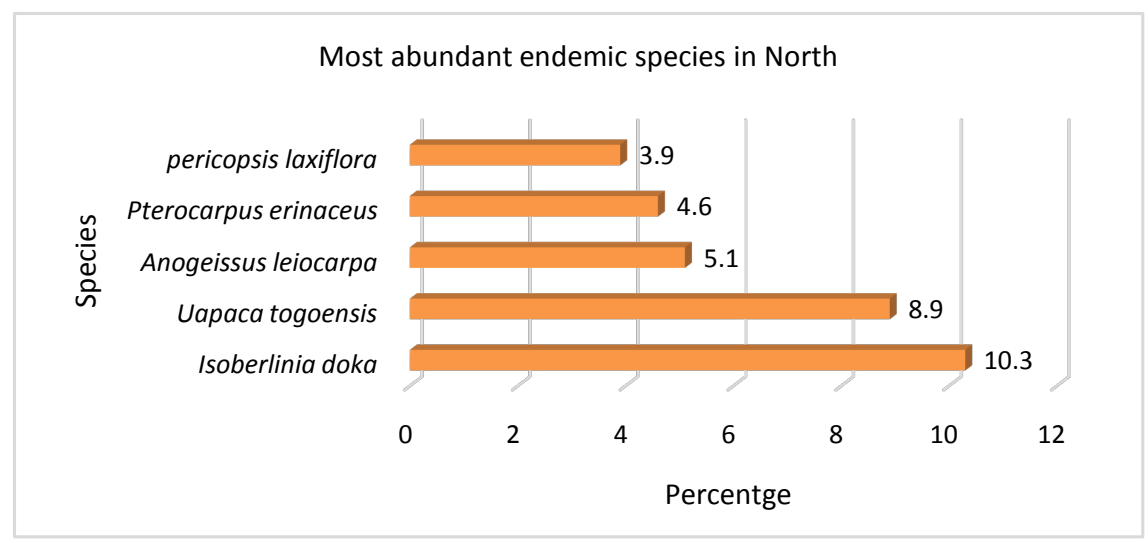

Figure 5. The abundance of endemic species in the agroecology in North of Cote d'Ivoire. 


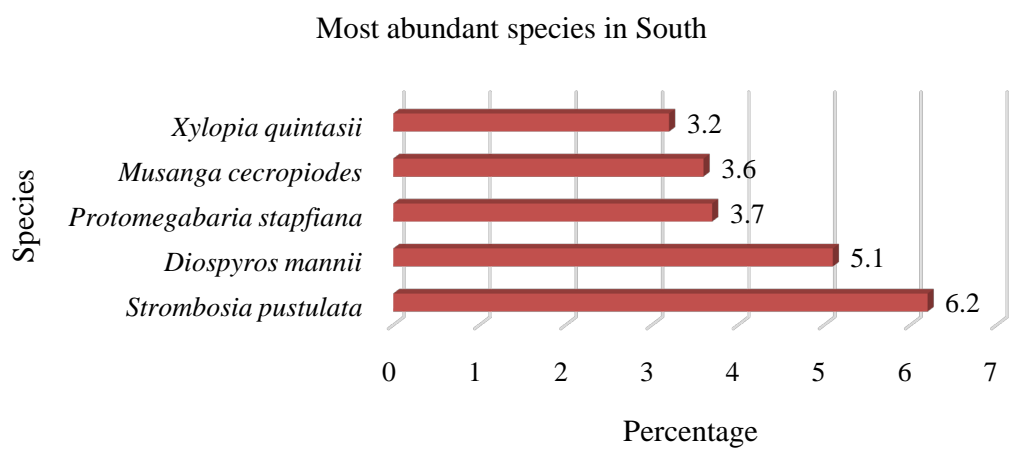

Figure 6. The abundance of endemic species in the agroecology in South of Cote d'Ivoire.

\section{DEFORESTATION AND FOREST DEGRADATION}
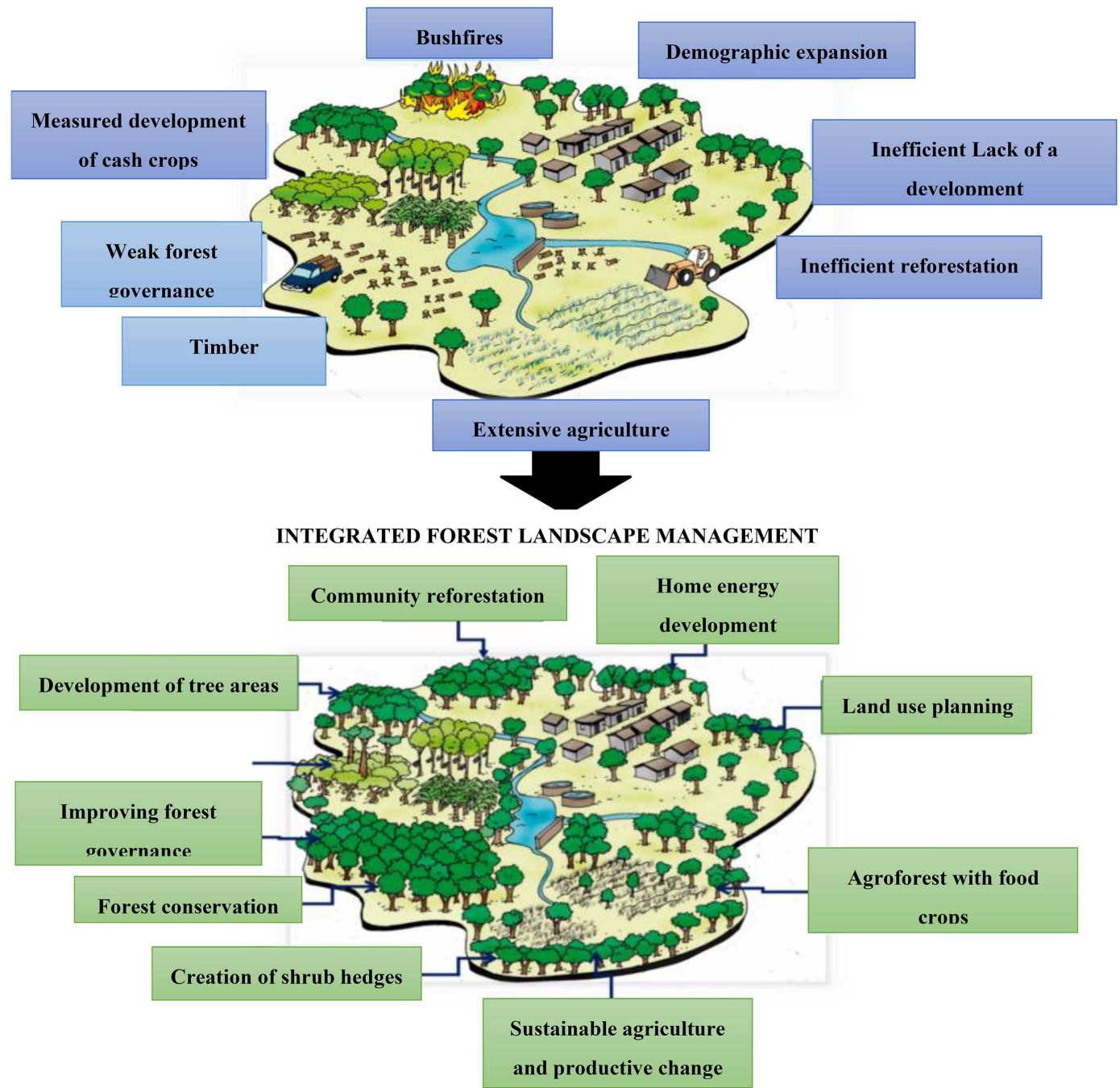

Figure 7. Development of an integrated management theory of deforestation engine [76].

abundance of rainfall due to their location in a humid forest zone. The average maximum temperature observed, on the other hand, is $21.8^{\circ} \mathrm{C}$, with the most 
significant temperature happening in the year 2019. This is entirely normal given the region's high humidity and steep terrain. In contrast to the other northern, central, and southern areas where rainfall is plentiful, the temperature in the center (Bouake) and south (Abidjan) is above $32^{\circ} \mathrm{C}$, while the temperature in the north (Ferkessédougou) is over $34^{\circ} \mathrm{C}$, making cash crops unsuitable for development.

\section{Discussion}

The expansion of agricultural plantations in the study region has been followed by immigration, which has resulted in a demographic shift. This is explained by the result of this concentration of the population in the rural areas is a high demand for accessible land (designated forests and parks) since the populations questioned are mostly agricultural. The large proportion of rural people living on the edges of classified forests and in the interior is mirrored in the fact that these farmers seek land suitable for cocoa production ( $71 \%$ cultivate in classified forests). The presence of these groups (indigenous, non-indigenous) in these categorized woods has resulted in the infiltrating of people engaging in two kinds of socioeconomic activity: agricultural operations and forestry activities. The infiltrator's agricultural operations inside the designated forest include cash crops and food crops (Table 2). Several types of procedures are carried out in categorized forests, including the production of charcoal and the harvesting of wood and non-wood forest products. These have hanged the vegetation pattern of most classed forests in the country's West, converting them to huge plantation crops and contributing to the extinction of indigenous species.

However, due to current population pressures and technological advancements, human activities in the environment have grown increasingly significant due to unsustainable land-use practices. Today, the natural forests of Cote d'Ivoire are estimated to be 2,800,490 hectares which seems disastrous owing to the development of cash cropland (Table 3). Despite 9340 hectares of restoration/reforestation efforts (Table 3 ), the balance remains uneven, particularly since people continue to besiege classified forests in violation of the law and the effects of agricultural and wood exploitation (Tables 3-5).

Indeed, human activities have altered animal and plant populations, resulting in effects on land-use patterns (forestry, agriculture, mining, and so on) that have significantly shaped the Ivorian natural environment. Their intensification has resulted in the simplicity or destruction of habitats, with one of the most severe effects being the loss of species and, as a result, the alteration of plant groups (Gmelia Arborea, Ceiba Pentandra, Muanga Cecropiodes) or animal (Armoured Crocodile, Panther Cercorpithecus Diana, Pygmy Hippopotamuses, Magistrate, and Chimpanzees Colobus) thus, illicit logging, particularly in Ivorian forest areas, and the accompanying illegal wood traffic (Table 4 and Table 5) contribute to forest degradation and biological wealth depletion. This discoverer of illicit wood exploitation may be attributed to inadequate forestry sector go- 
vernance. This dramatic loss and decrease of plant species and the vegetative cover impact the habitats of some animal species, making them vulnerable to poaching. The conservation of Ivorian woods must be considered a communal obligation to preserve an ecological balance for sustainable development, given the different global environmental and other concerns.

Furthermore, we observe that agriculture and logging are primarily responsible for the extinction of Ivorian biodiversity. Approximately $6.7 \%$ of rural forests, or 1,740,300 hectares, have been converted to agricultural land, while hundreds of wood trees are harvested in the rainforest, mountain, and mesophilic sectors. The expansion of cash crops in most classed forests, combined with poor agricultural yield, has encouraged rural people to violate forest protection regulations and live there. Cote d'Ivoire has lost a significant portion of its biodiversity due to the development of village plantation agriculture due to the considerable rise in surface area. From a socioeconomic standpoint, economic attraction, especially the worldwide price of agricultural commodities, is the most critical indirect influence in deforestation for all socio-professional groups. In addition to the overall growth rate of the Ivorian population $(2.55 \%$ per year, which equates to a population doubling over the past 30 years).

Due to particular migration, the country's forest areas have seen more significant demographic growth considerably [77] due to specific migration. These migratory patterns, along with the quest for land suitable for subsistence production (cocoa, coffee) in classed forests and rural areas (Table 2), have depleted most of the resource base. The proportion of wood species found in the Southern, Central, and Northern agroecology does not surpass 15\% (Figures 4-6). This issue is shown by the country's cocoa and palm output, the low degree of agricultural intensification, and therefore productivity, leading to more natural forests. The respondents emphasized the poor fertility of soils outside of the forest. The main reasons that encouraged farmers were favorable meteorological circumstances, such as abundant rainfall and temperatures conducive to the growth of cash crops, particularly in the forest west [78]. However, although these reasons were rarely respondents, it is worth mentioning that the effect of climate change in Cote d'Ivoire, through reduced rainfall in the savannah and dry zones, has resulted in lower yields, causing people to move to the fertile regions of thick forests. Non-natives, leading farmers, have moved in the forest heritage due to a significant wave of population movement from the West African sub-region of the Economic Community of West African States (ECOWAS) and are blamed for the deterioration of the classed forests. The significant number of families living in classified forests, with $50 \%$ of allogenic out of 1767 individuals questioned confirming owning cocoa plantations in the woods, demonstrates that they are primarily responsible for conversion. In truth, this is justified because, since the depletion of the Ivorian forest massif and the soil degradation in some areas of the nation, especially the Center and East, migrants have gradually opened up the Western front. First, the Center-Western (the 1950s 
and 1960s), then the South-West (1970s and 1980s), and lastly the West (1980s), resulting in immigration rates of $35 \%$ and $43 \%$ of the former South-Western Forest areas populations in 2001 [79].

The presence of these tribes in the classified forests (Allogenic: 50\%, Autochthons: $28 \%$, Allochthons: $22 \%$ ) has considerably reduced Cote d'Ivoire's biological resources. The presence of these populations in the classified forests can be explained by their search for land suitable for export crops such as coffee and cocoa, as their places of origin, which are often arid savannah areas (Burkina, Mali), did not allow them to grow these types of crops. This proportion may also be explained by the 2002 crisis, which occupied the country's north and a portion of its center. This resulted in the relocation of many families in search of a haven. As a result of being welcomed by their brothers residing on the edges of the classified woods, these people used the crisis to penetrate the majority of the classified forest region. During the crisis period (2002-2011), the absence of security agents from the "Société de Developpement des Forets" (SODEFOR) in charge of forest protection was noticed. The presence of infiltrating non-nationals is mainly made up of nationals from the neighboring nation.

The ethnic group "Gouro and Gagou” makes up infiltrating indigenous people [80]. The reason that these groups are rare in the forest is explained by the that they own all of the arable lands in the rural region. On the other hand, population growth happens along with other phenomena of rural economic development, increasing the pressure on deforestation since more land cleared can sustain a more significant population. As a result, an unending rise in population has resulted in the extinction of forests. The opening of these fronts, along with the loss of wildlife habitats, has had a significant impact on the Pygmy hippo, Armoured crocodile, Panther, Cercopithecus Diana, Magpie colobus, and Chimpanzees. This is the reason for the decline of endangered tree species.

Figure 8 depicts a model for preserving and restoring an ecological network to address ecological fragmentation in Cote d'Ivoire forest ecosystems. The goal is to encourage ecological and landscape linkages to maintain or establish ties between places of high biological value, thus promoting exchanges between animal and plant populations by creating an ecological network. This network is concerned with both forest conservation and forest cover restoration. This ecological network is built in two stages: 1) identifying and prioritizing sites of high ecological value (remarkable ecosystem such as protected areas, rare and endangered animal and plant species, and ecological potential); and 2) identifying ecological corridors to conserve, restore, or recreate between these sites. The idea is to connect biodiversity reservoirs from one region to another by increasing connectivity, i.e., the quality of the habitats traversed and the corridor's breadth, length, and sinuosity. This approach may aid in the preservation and protection of vulnerable habitats.

These findings indicate that the country's natural forest resources have been overexploited, resulting in the poverty, weakening, and loss of rural forest settings. 


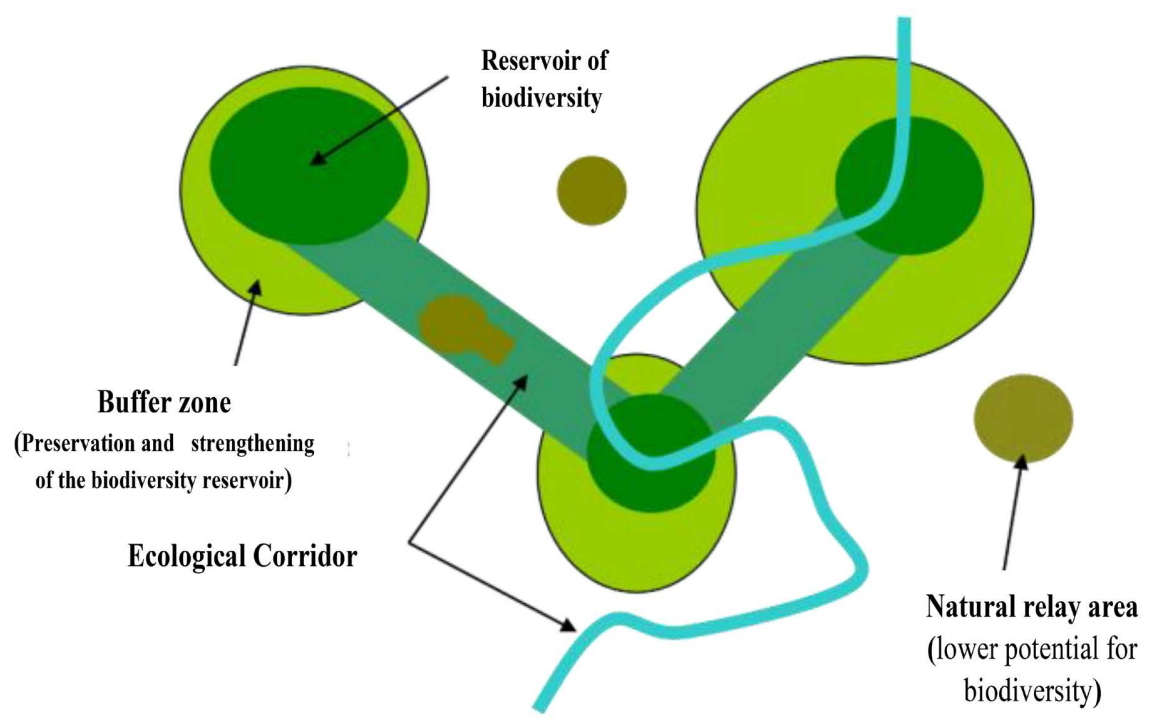

Figure 8. Ecology construction for the preservation and conservation of biodiversity [76].

Because of the rapid reduction in forest cover from 16 million to 2.5 million forests by 2020, intensive poaching of endangered animal species, uncontrolled bush fires and land clearing, and the exploitation of marketable timber, the population of many species has declined sharply. Some are threatened with extinction and small live-in areas, making them more vulnerable to poaching (Figure 3). Several unique animal and plant species have been recognized as being on the brink of extinction due to over-exploitation of forest resources and bushfires. The loss of the forest ecosystem results in a structural obstruction of the Ivorian agricultural system from an agro-economic standpoint. Indeed, the loss of forest reserves has made it impossible to reproduce agricultural civilization via the spread of pioneer fronts. This is being done in a confined area, which means that farmers are being compelled to establish production methods that no longer rely on the presence of a forest precedent capital for foods crops and perennial crops.

\section{Conclusion}

According to the findings of this research, Côte d'Ivoire's natural resources have decreased significantly in recent years. Rare and endangered species are only found in a few tiny forest areas, and these patches are very small. The significant causes of forest degradation are agricultural production and wood exploitation. In recent years, the nation's natural forest landmass has grown to $2,880,490 \mathrm{ha}$, a $6 \%$ increase over the previous year. As a result, the fact that farmers from neighboring countries are infiltrating the country's forests and engaging in cash crop agriculture demonstrates that Côte d'Ivoire lacks a unified land use policy that ensures the long-term development of the various land-related, mainly the forest, agricultural, and urban sectors. Using the Land-use Planner tool, a model for preserving and protecting ecological variety was developed. 


\section{Recommendation and Suggestion for Feature Research}

To assess the ecological consequences of cash crops such as cocoa on tropical rainforest and grassland by concentrating on changes in the area and ecosystem services of tropical rainforest and grassland using land-use intensity analysis and InVest software, which is based on satellite time-series imagery.

To research to protect the variety of wildlife species, habitats, and ecosystem services.

To research to protect open biomes' biodiversity, climate mitigation potential, and human livelihood advantages.

\section{Acknowledgements}

National Natural Science Fund Project for International and Regional Cooperation and Exchange "Sino-Argentian Cooperation Research on Temperate Grassland Degradation: Current Status Assessment and Recovery Strategies" (32061123005) and National Natural Science Fund Project "Joint Species Distribution Model Based Grassland Degradation Assessment and Potential Risk Projection in Hulun Buir Steppe" (41971061).

\section{Conflicts of Interest}

The authors declare no conflicts of interest regarding the publication of this paper.

\section{References}

[1] Butchart, S.H., Clarke, M., Smith, R.J., Sykes, R.E., Scharlemann, J.P., Harfoot, M., et al. (2015) Shortfalls and Solutions for Meeting National and Global Conservation Area Targets. Conservation Letters, 8, 329-337. https://doi.org/10.1111/conl.12158

[2] Suding, K., Higgs, E., Palmer, M., Baird Callicott, J., Anderson, C.B., Baker, M., et al. (2015) Committing to Ecological Restoration. Science, 348, 638-640. https://doi.org/10.1126/science.aaa4216

[3] Grassi, G., House, J., Dentener, F., Federici, S., den Elzen, Mi. and Penman, J. (2017) The Key Role of Forests in Meeting Climate Targets Requires Science for Credible Mitigation. Nature Climate Change, 7, 220-226. https://doi.org/10.1038/nclimate3227

[4] Timko, J., Le Billon, P., Zerriffi, H., Honey-Rosés, J., de la Roche, I., Gaston, C., et al. (2018) A Policy Nexus Approach to Forests and the SDGs: Tradeoffs and Synergies. Current Opinion in Environmental Sustainability, 34, 7-12. https://doi.org/10.1016/j.cosust.2018.06.004

[5] Katila, P., Pierce Colfer, C.J., de Jong, W., Galloway, G., Pacheco, P. and Winkel, G. (2019) Sustainable Development Goals. Cambridge University Press, Cambridge.

[6] Tsioumani, E. (2020) Convention on Biological Diversity: A Review of the Post-2020 Global Biodiversity Framework Working Group Negotiations. Environmental Policy and Law, 50, 55-59. https://doi.org/10.3233/EPL-200207

[7] Hansen, L.P., Heaton, J.C. and Li, N. (2008) Consumption Strikes Back? Measuring Long-Run Risk. Journal of Political economy, 116, 260-302.

https://doi.org/10.1086/588200 
[8] Bologna, M. and Aquino, G. (2020) Deforestation and World Population Sustainability: A Quantitative Analysis. Scientific Reports, 10, Article No. 7631. https://doi.org/10.1038/s41598-020-63657-6

[9] Oldekop, J.A., Rasmussen Vang, L., Agrawal, A., Bebbington, A.J., Meyfroidt, P., Bengston, D.N., et al. (2020) Forest-Linked Livelihoods in a Globalized World. Nature Plants, 6, 1400-1407. https://doi.org/10.1038/s41477-020-00814-9

[10] Oldekop, J.A., Gabay, M., Humphreys, D., Kamoto, J.F.M., Mutta, D.N., Song, C., et al. (2021) A Framework for Analysing Contextual Factors Shaping Forest-Poverty Dynamics. Forest Policy and Economics, 132, Article ID: 102591. https://doi.org/10.1016/j.forpol.2021.102591

[11] Malhi, Y., Baldocchi, D. and Jarvis, P. (1999) The Carbon Balance of Tropical, Temperate and Boreal Forests. Plant, Cell \& Environment, 22, 715-740.

https://doi.org/10.1046/j.1365-3040.1999.00453.x

[12] Myers, N., Mittermeier, R.A., Mittermeier, C.G., da Fonseca, G.A.B. and Kent, J. (2000) Biodiversity Hotspots for Conservation Priorities. Nature, 403, 853-858. https://doi.org/10.1038/35002501

[13] Bradshaw, C.J., Sodhi, N.S. and Brook, B.W. (2009) Tropical Turmoil: A Biodiversity Tragedy in Progress. Frontiers in Ecology and the Environment, 7, 79-87. https://doi.org/10.1890/070193

[14] Pan, Y., Birdsey, R.A., Fang, J., Houghton, R., Lewis, S.L., Kauppi, P.E., et al. (2011) A Large and Persistent Carbon Sink in the World's Forests. Science, 333, 988-993. https://doi.org/10.1126/science.1201609

[15] Poorter, L., van der Sande, M.T., Thompson, J., Arets, E.J.M.M., Alarcón, A., Álvarez-Sánchez, J., et al. (2015) Diversity Enhances Carbon Storage in Tropical Forests. Global Ecology and Biogeography, 24, 1314-1328. https://doi.org/10.1111/geb.12364

[16] Kovshov, V.A., Zalilova Z.A., Lukyanova M.T. and Sagadeeva E.F. (2021) Sustainable Development Strategies for Regional Based on Innovation Potential. In: Bogoviz A.V., Ed., The Challenge of Sustainability in Agricultural Systems, Springer, Cham, 595-603. https://doi.org/10.1007/978-3-030-73097-0 67

[17] Sullivan, H. and Skelcher, C. (2017) Working across Boundaries: Collaboration in Public Services. Macmillan International Higher Education, London.

[18] DeFries, R.S., Foley, J.A. and Asner, G.P. (2004) Land-Use Choices: Balancing Human Needs and Ecosystem Function. Frontiers in Ecology and the Environment, 2, 249-257. https://doi.org/10.1890/1540-9295(2004)002[0249:LCBHNA]2.0.CO;2

[19] Foley, J.A., Defries, R., Asner, G.P., Barford, C., Bonan, G., Carpenter, S.R., et al. (2005) Global Consequences of Land Use. Science, 309, 570-574.

https://doi.org/10.1126/science.1111772

[20] Muir, G. (2021). The Role of Non-Wood Forest Products in Diets and Livelihoods: Quantifying the Contributions. Ph.D. Thesis, University of Padova, Padova.

[21] Oszwald, J. (2005) Dynamique des formations agroforestières en Côte d'Ivoire (depuis les années 1980 aux années 2000): Suivi par télédétection et développement d'une approche cartographique. Lille 1.

[22] Poorter, L. (2004) Biodiversity of West African Forests: An Ecological Atlas of Woody Plant Species. CABI, Wallingford. https://doi.org/10.1079/9780851997346.0000

[23] Mittermeier, R.A., Wallis, J., Rylands, A.B., Ganzhorn, J.U., Oates, J.F., Williamson, E.A., et al. (2009) Primates in Peril: The World's 25 Most Endangered Primates 2008-2010. Primate Conservation, 24, 1-57. https://doi.org/10.1896/052.024.0101 
[24] McShane, T.O., Hirsch, P.D., Trung, T.C., Songorwa, A.N., Kinzig, A., Monteferri, B., et al. (2011) Hard Choices: Making Trade-Offs between Biodiversity Conservation and Human Well-Being. Biological Conservation, 144, 966-972. https://doi.org/10.1016/j.biocon.2010.04.038

[25] Cronin, D.T., Libalah, M.B., Bergl, R.A. and Hearn, G.W. (2014) Biodiversity and Conservation of Tropical Montane Ecosystems in the Gulf of Guinea, West Africa. Arctic, Antarctic, and Alpine Research, 46, 891-904. https://doi.org/10.1657/1938-4246-46.4.891

[26] Gockowski, J. and Sonwa, D. (2011) Cocoa Intensification Scenarios and Their Predicted Impact on $\mathrm{CO}_{2}$ Emissions, Biodiversity Conservation, and Rural Livelihoods in the Guinea Rain Forest of West Africa. Environmental Management, 48, 307-321. https://doi.org/10.1007/s00267-010-9602-3

[27] Leh, M.D., Matlock, M.D., Cummings, E.C. and Nalley, L.L. (2013) Quantifying and Mapping Multiple Ecosystem Services Change in West Africa. Agriculture, Ecosystems \& Environment, 165, 6-18. https://doi.org/10.1016/j.agee.2012.12.001

[28] Kouao, M.L., Koffi Bene, J.-C., Soulemane, O., Djaha, A.K., Yao, A. and Kone, I. (2020) Nature and Management of Human-Elephant Conflicts around the Dassioko Classified Forest on the Ivorian Coastline. Journal of Animal \& Plant Sciences, 44, 7745-7757.

[29] Keenan, R.J., Reams, G.A., Achard, F., de Freitas, J.V., de Freitas, J.V. and Lindquist, E. (2015) Dynamics of Global Forest Area: Results from the FAO Global Forest Resources Assessment 2015. Forest Ecology and Management, 352, 9-20. https://doi.org/10.1016/j.foreco.2015.06.014

[30] Bi, Z.G., Kouame, D., Kone, I. and Adou Yao, C.Y. (2013) Diversité végétale et valeur de conservation pour la Biodiversité du Parc National du Mont Péko, une aire protégée, menacée de disparition en Côte d'Ivoire. Journal of Applied Biosciences, 71, 5753-5762. https://doi.org/10.4314/jab.v71i1.98820

[31] Vroh, B.T.A., Tiébré, M.-S., Ouattara, D. and N’Guessan, K.É. (2014) La réserve forestière Dékpa d'Agbaou, un exemple de conservation de la diversité végétale sur les sites miniers de la Côte d'Ivoire [Forest Reserve of Dékpa Agbaou, an Example of Plant Diversity Conservation on Mine Sites in Côte d'Ivoire]. International Journal of Innovation and Applied Studies, 6, 162-171.

[32] Koudou, A.N. and Vlosky, R.P. (1998) Government Forest Policies in Cote D'Ivoire. Louisiana Forest Products Laboratory. Baton Rouge: Louisiana State University Agricultural Center. www.lfpdc.lsu.edu/publications/working papers/wp29.pdf

[33] Domson, O. and Vlosky, R.P. (2007) A Strategic Overview of the Forest Sector in Ghana. Louisiana Forest Products Development Center, Louisiana.

[34] Oduro, K., Mohren, G.M.J., Affum-Baffoe, K. and Kyereh, B. (2014) Trends in Timber Production Systems in the High Forest Zone of Ghana. International Forestry Review, 16, 289-300. https://doi.org/10.1505/146554814812572458

[35] N'Guessan, A., Akpa, Y. and N'GO, Y. (2019) Cartographie de la dynamique du couvert végétal de la forêt Classée d'Agbo 1 Côte d'Ivoire. Agronomie Africaine, 31, 88-99.

[36] Parr, A. (2014) The Wrath of Capital: Neoliberalism and Climate Change Politics. Columbia University Press.

[37] Fleischman, F., Basant, S., Chhatre, A., Coleman, E.A., Fischer, H.W, Gupta, D., et al. (2020) Pitfalls of Tree Planting Show Why We Need People-Centered Natural Climate Solutions. BioScience, 70, 947-950. https://doi.org/10.1093/biosci/biaa094

[38] Veldman, J.W., Overbeck, G.E., Negreiros, D., Mahy, G., Le Stradic, S., Wilson Fer- 
nandes, G., et al. (2015) Where Tree Planting and Forest Expansion Are Bad for Biodiversity and Ecosystem Services. BioScience, 65, 1011-1018. https://doi.org/10.1093/biosci/biv118

[39] Bastin, J.-F., Finegold, Y., Garcia, C., Mollicone, D., Rezende, M., Routh, D., et al. (2019) The Global Tree Restoration Potential. Science, 365, 76-79.

https://doi.org/10.1126/science.aax0848

[40] Bond, P. (2019) Blue Economy threats, Contradictions and Resistances Seen from South Africa. Journal of Political Ecology, 26, 341-362. https://doi.org/10.2458/v26i1.23504

[41] Lewis, S.L., Wheeler, C.E., Mitchard, E.T.A. and Koch, A. (2019) Restoring Natural Forests Is the Best Way to Remove Atmospheric Carbon. Nature Publishing Group, Berlin. https://doi.org/10.1038/d41586-019-01026-8

[42] Jin, S.Q., Zhang, B., Wu, B., Han, D.M., Hu, Y., Ren, C.C., Zhang, C.Z., Wei, X., Wu, Y., Mol, A.P.J., Reis, S., Gu, B.J. and Chen, J. (2021) Decoupling Livestock and Crop Production at the Household Level in China. Nature Sustainability, 4, 48-55. https://doi.org/10.1038/s41893-020-00596-0

[43] Skidmore, A.K., WANG, T., DE BIE, K. and PILESJÖ, P. (2019) Comment on "The Global Tree Restoration Potential”. Science, 366, Article No. aaz0111. https://doi.org/10.1126/science.aaz0111

[44] Álvarez, M.D. (2003) Forests in the Time of Violence: Conservation Implications of the Colombian War. Journal of Sustainable Forestry, 16, 47-68.

https://doi.org/10.1300/J091v16n03 03

[45] Bannon, I. and Collier, P. (2003) Natural Resources and Violent Conflict: Options and Actions. World Bank Publications, Washington DC. https://doi.org/10.1596/0-8213-5503-1

[46] Gorsevski, V., Geores, M. and Kasischke, E. (2013) Human Dimensions of Land Use and Land Cover Change Related to Civil Unrest in the Imatong Mountains of South Sudan. Applied Geography, 38, 64-75. https://doi.org/10.1016/j.apgeog.2012.11.019

[47] Holl, K.D. and Brancalion, P.H. (2020) Tree Planting Is Not a Simple Solution. Science, 368, 580-581. https://doi.org/10.1126/science.aba8232

[48] Yao, C.A. and Roussel, B. (2007) Forest Management, Farmers' Practices and Biodiversity Conservation in the Monogaga Protected Coastal Forest in Southwest Cote d'Ivoire. Africa, 77, 63-85. https://doi.org/10.3366/afr.2007.77.1.63

[49] Bakayoko, A., Martin, P., Chatelain, C., Traore, D. and Gautier, L. (2011) Diversity, Family Dominance, Life Forms and Ecological Strategies of Forest Fragments Compared to Continuous Forest in Southwestern Côte d'Ivoire. Candollea, 66, 255-262. https://doi.org/10.15553/c2011v662a2

[50] Venance-Pâques Gniayou, K., Affia Sonmia Francia, K., N'guessan Lucien, D., Kouamé Kra Modeste, A. and Yao Constant Yves, A. (2021) Socio-Economic Assessment of Different Cocoa Agroforestry Systems in the Forest-Savannah Transition Zone in Central Côte d'Ivoire. Forests, Trees and Livelihoods, 30, 195-212. https://doi.org/10.1080/14728028.2021.1958064

[51] Massa, B. (2021) Orthoptera Tettigoniidae as Indicators of Biodiversity Hotspots in the Guinean Forests of Central and West Tropical Africa. Zootaxa, 4974, 401-458. https://doi.org/10.11646/zootaxa.4974.3.1

[52] Allnutt, T.F., Asner, G.P., Golden, C.D. and Powell, G.V.N. (2013) Mapping Recent Deforestation and Forest Disturbance in Northeastern Madagascar. Tropical Conservation Science, 6, 1-15. https://doi.org/10.1177/194008291300600101 
[53] Barima, Y.S.S., Kouakou, A.T.M., Bamba, I., Sangne, Y.C., Godron, M., Andrieu, J., et al. (2016) Cocoa Crops Are Destroying the Forest Reserves of the Classified Forest of Haut-Sassandra (Ivory Coast). Global Ecology and Conservation, 8, 85-98. https://doi.org/10.1016/j.gecco.2016.08.009

[54] Tankoano, B., Hien, M., Hyppolite Dibi, N., Sanon, Z., Yameogo, J.T. and Somda, I. (2015) Dynamique spatio-temporelle des savanes boisées de la forêt classée de Tiogo au Burkina Faso. International Journal of Biological and Chemical Sciences, 9, 1983-2000. https://doi.org/10.4314/ijbcs.v9i4.23

[55] Kouakou, J.-L., Gonedelé, Bi.S., Bitty, E.A., Kouakou, C., Yao, A.K., Kassé, K.B., et al. (2020) Ivory Coast without Ivory: Massive Extinction of African Forest Elephants in Côte d'Ivoire. PLoS ONE, 15, Article ID: 0232993.

https://doi.org/10.1371/journal.pone.0232993

[56] Kouakou, K.A., et al. (2015) Diversité végétale post-conflits armés de la Forêt Classée du Haut-Sassandra (Centre-Ouest de la Côte d'Ivoire). Journal of Animal and Plant Sciences, 26, 4058-4071.

[57] Assale, A.A.Y., Barima, Y., Kouakou, K., Kouakou, A. and Bogaert, J. (2016) Agents de dégradation d'une aire protégée après une décennie de conflits en Côte d'Ivoire: Cas de la forêt classée du Haut-Sassandra. International Journal of Innovation and Scientific Research, 22, 123-133.

[58] Tra Bi, Z., Brou, Y.T. and Mahé, G. (2015) Analyse par télédétection des conditions bioclimatiques de végétation dans la zone de contact forêt-savane de Côte d'Ivoire: cas du" V" Baoulé. XXVIIIe Colloque de I Association Internationale de Climatologi, Liège, 6-10 September 2015, 78-83.

[59] Verdeaux, F. (1999) Economic Policy for Improving Forest Resources: Cote-d'Ivoire, 1900-1990 [Dynamics of Forest Use, Forester Paradigm, Sociological Rationalities]. Autrepart (France).

[60] Yao, T.B., et al. (2005) Risques de déforestation dans le domaine permanent de l'état en Côte d'ivoire: Quel avenir pour ces derniers massifs forestiers? Télédétection, 5, 17-33.

[61] Brou, Y.T., Oszwald, J., Bigot, S. and Servat, E. (2009) Impacto de los cambios bioclimáticos y la deforestación en áreas rurales.¿ Cuál es la solución para la agricultura en Costa de Marfil? Cuadernos Geográficos, 45, 13-29.

[62] Pomel, S. and Salomon, J.-N. (1998) La déforestation dans le monde tropical. Presses Univ de Bordeaux, Pessac. https://doi.org/10.4000/books.pub.1379

[63] Leonard, E. and Ibo, J. (1994) Appropriation and Management of the Forest Capital of Cote d'Ivoire. Politique Africaine (France), 25-36.

[64] Tutu, K. and Akol, C. (2009) Reversing Africa's Deforestation for Sustainable Development. In: Yanful, E.K., Ed., Appropriate Technologies for Environmental Protection in the Developing World, Springer, Dordrecht, 25-34. https://doi.org/10.1007/978-1-4020-9139-1 4

[65] Koffi, K.J., Kouassi, A.F., Adou Yao, C.Y., Bakayoko, A., Ipou, I.J. and Bogaert, J. (2015) The Present State of Botanical Investigations in Côte d'Ivoire. Biodiversity Informatics, 10, 56-64. https://doi.org/10.17161/bi.v10i2.5007

[66] Koné, M., Kouadio, Y.L., Neuba, D.F.R., Malan, D.F. and Coulibaly, L. (2014) Évolution de la Couverture Forestière de la Côte D’ivoire des Années 1960 au Début du 21e Siècle/ [Evolution of the Forest Cover in Cote D'ivoire since 1960 to the Beginning of the 21st Century]. International Journal of Innovation and Applied Studies, 7, 782-794.

[67] Metternicht, G. and Suhaedi, E. (2003) Cartographic Tools for Improved Spatial 
Planning for Rural Areas: Multi-Criteria Decision Making Techniques and Geographic Information Systems. Proceedings of the 21 st International Cartographic Conference (ICC) Durban, 2003.

[68] Sayer, J.A., Margules, C., Boedhihartono, A.K., Sunderland, T., Langston, J.D., Reed, J., et al. (2017) Measuring the Effectiveness of Landscape Approaches to Conservation and Development. Sustainability Science, 12, 465-476.

https://doi.org/10.1007/s11625-016-0415-z

[69] Hicks, B., Galdorisi, G. and Truver, S.C. (2012) The Aegis Bmd Global Enterprise: A "High End" Maritime Partnership. Naval War College Review, 65, 65-80.

[70] García-Rangel, S. and Andígena, F. (2008) Progress Report V.

[71] Sayer, J., Margules, C., Boedhihartono, A.K., Dale, A., Sunderland, T., Supriatna, J., et al. (2015) Landscape Approaches: What Are the Pre-Conditions for Success? Sustainability Science, 10, 345-355. https://doi.org/10.1007/s11625-014-0281-5

[72] Sayer, J., Sunderland, T., Ghazoul, J., Pfund, J.-L., Sheil, D., Meijaard, E., et al. (2013) Ten Principles for a Landscape Approach to Reconciling Agriculture, Conservation, and Other Competing Land Uses. Proceedings of the National Academy of Sciences, 110, 8349-8356. https://doi.org/10.1073/pnas.1210595110

[73] Garrett, J.K., Clitherow, T.J., White, M.P., Wheeler, B.W. and Fleming, L.E. (2019) Coastal Proximity and Mental health among Urban Adults in England: The Moderating Effect of Household Income. Health \& place, 59, Article ID: 102200. https://doi.org/10.1016/j.healthplace.2019.102200

[74] Brown, M.I. (2013) Redeeming REDD: Policies, Incentives and Social Feasibility for Avoided Deforestation. Routledge, London and New York.

[75] Taylor, R. and Streck, C. (2018) The Elusive Impact of the Deforestation-Free Supply Chain Movement. World Resources Institute, Washington DC.

https://wriorg.s3.amazonaws.com/s3fs-public/endingtropical-deforestation-supplychain-movement.pdf

[76] REDD+, Cote D'Ivoire (2017) Strategie Nationale REDD+ pour la Cote d'ivoire. P. 121. https://chm.cbd.in

[77] Balac, R. (2001) Dynamiques migratoires et économie de plantations. La Côte d'Ivoire à l'aube du XXIe siècle. Défis démographiques et développement durable, Paris, Karthala, 195-231.

[78] Muller, K.J., Théophile, L. and Bachir, S.M. (2013) Analyse de tendances dans la relation pluie-débit dans un contexte de changements climatiques: Cas du bassin versant du N'zo-Sassandra (Ouest de la Côte d'Ivoire). International Journal of Innovation and Applied Studies, 2, 92-103.

[79] Adou, D.L. (2020) Explosion demographique et mutations du paysage urbain de Bonon (centre-ouest de la Cote d'Ivoire). Journal de la Recherche Scientifique de I Université de Lomé, 22, 219-236.

[80] Kokou, K. (2010) Installation d'un réseau de placeaux permanents de suivi de la dynamique des forêts classées de Côte d'Ivoire PD 53/00 REV.3 (F). 